\title{
Father absence and adolescents as a challenge to youth ministry
}

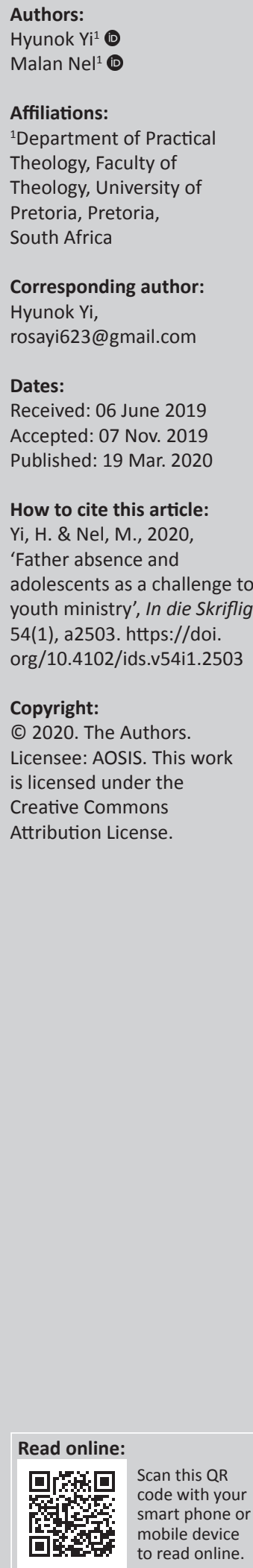

Youth ministry is to help youth - children, adolescents and young adults - to become what they were created and called to be. However, many local churches fail to notice that adolescents growing up without a father figure are an integral part of the faith community. They are inclined to neglect the father's role relative to these adolescents in a local church. The responsibility of faith communities towards children and adolescents with absent or uninvolved fathers is unquestionable. This study has its focus on youth ministry and specifically the topic of absent or uninvolved fathers and adolescents without a father figure as challenges for youth ministry in an attempt to address the concern for an effective youth ministry towards those young people with an inclusive and congregational approach. The article focuses on an empirical research with two groups: adolescents growing up without a father figure and local pastors of these adolescents. Twenty-one adolescents without a father figure and 12 local pastors of these adolescents were approached to participate in qualitative interviewing. This article seeks to describe how the adolescents feel about the absence of their fathers and God as their Father. It also presented the situation of the local church with adolescents with absent fathers and indicates that there is a lack of interaction between them and pastors or congregations.

Keywords: youth ministry; father absence; adolescence; empirical study; extended family; an inclusive congregational approach.

\section{Introduction}

The researcher, as a missionary, works with black communities in Gauteng, Mpumalanga and Limpopo, and has experienced challenges with children and adolescents with absent or uninvolved fathers. Their unwed mothers or grandmothers raise most of them. The researcher meets several teenage mothers who are high school students and have unplanned babies. After a sexual relationship, the male partner, in most cases, deserts his pregnant partner.

Nel (2000:63) identifies youth ministry as an integral part of 'building up the local church'. However, there is a lack of conception regarding the full role of a youth ministry and often young people are neglected in the local church.

However, these children and adolescents have become a challenge for youth ministry and within South African society. According to Statistics South Africa (Stats SA 2017), there are over 60\% of fathers who are absent. Forty-one per cent of children (7.5 million) live with their mothers only (Hall \& Sambu 2016). Adolescents without a father figure do not find it easy to understand the role of a father and may have a negative feeling and concept regarding God the Father. If fathers are so emotionally distant from their children, the children could have difficulty in sensing the closeness and tenderness of God the Father. Abused children and adolescents have difficulty in experiencing the love of God and the tenderness of God (Krohn \& Bogan 2001; Meyer 2018).

When local churches concern themselves with such a challenge, situation or context, they must think of the four tasks of a hermeneutical circle: 'What is going on?', 'Why is this going on?', 'What ought to be going on?', and 'How might we respond?' Practical theology attempts to integrate theory and praxis, 'the theological ideal and the empirical reality' (Heitink 1999:8; Jacober 2011:11; Nel 2018:15-16). The term praxis is more than practice. Forrester (2005:7) offers a clear definition: 'Praxis is on the reflective or meaning content of behaviour, the integral interaction between theory and practice, refers to transformative practice.'

The problem statement of this research is as follows: The lack of theological perspective and an inclusive and congregational approach for father-absent youth leads to negative effects and the efficiency of a youth ministry in the local church. 


\section{Reasons for father absence}

There are many reasons given why a large number of young people never knew their biological fathers or live without them.

Some of the primary reasons of father absence are unemployment, divorce, HIV epidemic and the cultural factor:

- Unemployment: According to Stats SA (2018), South Africa's unemployment rate came in at $26.7 \%$, with 5.98 million people unemployed. Of the black population, $61 \%$ was classified as poor while only $1 \%$ of the white population fell into the same category (Wilson 2006:28). Many poor fathers are not living with their children, moving from one place to another to find a job.

- Divorce: As the divorce rate is increasing due to inter alia adultery, abuse, alcohol and financial problems, fatherabsent families have also increased. According to Stats SA (2015), 42.9\% of black couples divorced in 2015. Today many people are no longer prepared to take the time to try to sort their problems out (Thomas 2017).

- HIV epidemic: The HIV epidemic results in father-absent families because of the high death rates of men, that impact women and children in families and communities (Makusha, Richter \& Chikovore 2013:74-75). More than 5.7 million people in South Africa are living with HIV, including 300000 children. There are about 3.7 million orphans - close to half of them have lost both their parents due to HIV-related illnesses. 150000 children are living in child-headed households. Familial and financial structures are destroyed (UNICEF South Africa 2011).

- Cultural factor: Cultural factors such as 'lobola' can be a reason for father absence. 'Lobola' means property in cash or in kind that a prospective husband or the head of his family undertakes to give to the head of the prospective wife's family in consideration of a customary marriage. Today, when paid in cash, 'lobola' often amounts to 'several thousand rand'. After 'lobola' is paid, the couple's marriage would be legalised. If a child is born out of wedlock, a man may be limited or denied seeing the child until he pays 'lobola'. The woman's family dismisses him as being irresponsible and useless. The unemployed and poor young men will be excluded from being involved in their children's lives (cf. Mosotho, Louw \& Calitz 2011).

\section{Father involvement in child and adolescent development}

The father's role is as important in child and adolescent development as the mother's role. A nurturing father contributes to his children and adolescents' development in various fields such as cognitive, intellectual, behaviour, gender role and faith development (Santrock 2007:17).

Parental support facilitates a positive relationship, positive outcomes of academic achievement and self-concept development (Rohner 2004). The resident father's involvement is related to the child's performance in verbal intelligence, more complex vocabulary, more meaningful phrases and cognitive ability (Bronte-Tinkew et al. 2008; Lewis 1997:121-142). According to Piaget (1972:1-12), adolescents experience changes at the cognitive level from concrete to formal operations and adult thinking becomes possible at this stage. Father-son interaction is correlated in the perceptivity. The male adolescents in the high-achieving group perceived themselves as more similar to their fathers than boys in the low-achieving group (Oswald \& Süss 1994:348-349).

Several studies (Eisenberg \& Morris 2004:163-165; Hoffman 1996; Walker \& Hennig 1999) found that fathers have a significant impact on their children's moral development such as aggression, dependency, generosity, honesty and delinquency. According to these studies:

- Generous boys perceived their fathers as warmer and more nurturing;

- The fathers of aggressive men caused the aggression in their sons;

- The child who is honest, perceived his or her father more positively than a child who is dishonest; and

- A lack of as well as excess parental discipline is related to juvenile delinquency.

A nurturing father provides the child with a good model and motivates him or her to adopt the father's behaviour. When the father and his children have a close and warm relationship, the children are advantaged in their moral development.

One of the great challenges in adolescence, according to Erikson (1963:273), is the crisis of identity. To succeed in the developing of an awareness of identity, the crisis of a lack of a sense of trust, autonomy, initiative and industry, as previously mentioned, must be resolved successfully.

The point to note is the significance of key persons at each stage of a child's development: both parents, family and the community.

The most important key role models in a youth's life are his or her parents. Even though within parent-adolescent relationships conflict is common, conflict management depends on the quality of parent-adolescent communication and the degree of relationship closeness (Bush \& Peterson 2013:292-293). It has been found that the gender role development of children in their behaviour and attitudes are influenced directly and indirectly by their parents. During adolescence, adolescents see themselves as masculine and feminine. They adopt their parents and other family members as primary role models in influencing their ideas about gender and behaviour (Spence \& Hall 1996).

Similarly, parents play a very significant and essential role in shaping the values and faith of children and adolescents. Religious parents, family climate and spiritual life are the important factors of faith development in children and adolescents. Parental spiritual help supports the children's own faith development (Schulze 2012:292-293). 


\section{A brief reflection on youth ministry with an inclusive and congregational approach}

Adolescents with absent or uninvolved fathers may be one of the missing parts of the whole body in local churches. The metaphor of the body of Christ expresses the importance of the corpus of members being the plan and making the plan work in unity (Nel 2009).

\section{Nel (2000) defines youth ministry as:}

[A] comprehensive and inclusive congregational ministry in which God comes, through all modes of ministry and with especial regard to parents (or their substitutes), with a differentiated focus, to youth (as an integral part of the local church) and also with and through the youth in the local church, to the world. (p. 97)

All modes of ministry can be clustered into four main ministries, namely Kerygma, Leitourgia, Koinonia and Diakonia:

- Kerygma: The people of God live with faith and 'faith comes from hearing the message, and the message is heard through the Word of Christ' (Rm 10:17 - New International Version [NIV]). The ministry of preaching or proclaiming must enter the here and now of the congregation and proclaim the new state of affairs that has arrived with God's coming (Nel 2000:89).

- Leitourgia: Worship is the particular time that a congregation gathers deliberately seeking to encounter God in Christ, who gives them power for their life, community, meaning and hope in their life. The congregation serves God through worship, songs of praise, thanksgiving, the confession of sin, prayers, offerings, et cetera. (Callahan 1994; 2010:84; Schnase 2007:33-34).

- Koinonia: is the congregation's spiritual fellowship experienced as one in body with Christ. The ministry of mutuality should be intensely focused on the children, adolescents and young adults who need family relationships (Nel 2000:92).

- Diakonia: 1 Peter 4:10 says, 'Each one should use whatever gift he has received to serve (diakoneo) others, faithfully administering God's grace in its various forms' (NIV). Ubuntu is an ancient Southern African word meaning 'humanity with others'. Ubuntu is being part of the community and becomes part of the identity of the individual as a member of the congregation (Breed \& Semenya 2015; Dietrich et al. 2014:17). The congregation must serve the youth by using their gifts, and the youth must learn and practice diakonia to the people who are in need.

The youth must be reached through all modes of ministry and have a place to worship the King while serving the coming of his kingdom (Nel 2001:6; 2018:202-203).

The inclusive congregational approach integrates young people into congregational life as full partners in every aspect of God's call to the Christian faith community. Young people are an integral part of God's people and of the body of Christ, who cannot be separated from the entire church (Nel 2018:206).

\section{Father-absent adolescents as an extended Christian family of the local church}

To understand the metaphor of the body of Christ, the following question must be asked: 'What is the congregation?' $\mathrm{Nel}$ (2005:36-37) states that when the congregation becomes our congregation, the congregation comes to be seen as existing for the sake of the we, much more than for the sake of the not-yet-we. According to Devries (1994:116), the extended Christian family is a community of believers who affirm and encourage growth towards Christian maturity. This community of believers becomes a vital link in helping the father-absent youth mediate the transition from their place in their father-absence families to their place in the Christian faith community (Dean \& Foster 1998:80). God calls his people to unity within the one body of Christ, who interacts with one another as family members (Eph 4:4). This new Christian family is the church, which affirms a sense of identity as children of God and believers within the faith community (Stinson \& Jones 2011:15). Even though church members have various social classes, races, ages and backgrounds, they are the children of God who know one another intimately and become the one body of Christ. Therefore, the local church needs to have a strong family relationship between congregations and youth who live without a father figure.

\section{The role of the pastor and congregation as a father figure towards adolescents with an absent or uninvolved father}

The pastor is the model that the church often looks to for fathering. The pastor must have a loving heart and understanding toward youth without a father figure. Youth ministry is not a programme, but a relational ministry. Empathy is a feeling which touches relationships that give rise to people and a reflex to build new relationships (Root 2013:91). The pastor as well as congregation are very important to the youth as godly models and non-familial natural mentors. The congregation is a collection of righteous adults in the faith community, who can give advice about such serious issues in the youth's daily life. The congregation is an important place for the youth to make significant contact with adults other than family members (Smith \& Denton 2005:61-65). Dean (2010:3-4) declares that 'The religiosity of American teenagers must be read primarily as a reflection of their parents' religious devotion and by extension, that of their congregations.' Meaningful relationships between adults and the youth in Christian faith, will give young people the opportunity to form an identity and know 'who they are in God's eyes' (Dean \& Foster 1998:45-46). 


\section{Empirical research plan Research aims and questions}

This research has four general aims:

- to understand the father's role as a spiritual leader;

- to describe the role of the father in child and adolescent development, emphasising the unhealthy influence of father absence on the child and adolescent;

- to discuss findings about the present situation of the local church regarding the youth who live without a biological father; and

- to examine the implications of the research findings for inclusive congregational youth ministry.

Father-absent adolescent participants answered 19 questions within four main themes, namely: (1) description of participants' relationships with their fathers; (2) description of the participants' awareness of fathers' absence; (3) the influence of father absence on the participants' relationship with God; and (4) description of the context of the participants' relationship with pastors and church.

The following questions were put to the adolescents with absent or uninvolved fathers:

- Do you have contact with your father?

- Do you hear from your father?

- When last did your father make contact with you?

- What do you know about your father?

- How do you feel about the word father?

- If you had regular contact with your father, and what would have wished your relationship to be?

- When did you think that you needed your father?

- If you become a parent, how would you treat your children?

- How are you feeling about your absent father?

- Do you have any negative feelings about your father, even if you may not know your father?

- How do you feel when someone says, 'Heavenly Father', or 'God, our Father'?

- Could you please try to explain why you feel that way?

- Have you experienced any negative feelings towards the 'Heavenly Father', or of 'God, our Father?'

- Have you experienced the closeness and tenderness of God as Father in your life?

- Do you think that your church or pastor understands your painful feelings and difficult situation?

- If you said yes, could you please tell me when you felt that your church or pastor understood?

- Have you thought about your pastor or any church member as your father?

- If you said yes, when did you think that?

- Could you please name three things that you would like your church or pastor to help you with?

Local senior pastor participants answered 11 questions within three main themes, namely: (1) describe the participants' recognition of young people who live without a father figure; (2) the participants' descriptions of relationships with these young people; and (3) descriptions of the participants' awareness of fathers' absence.

The following questions were put to the pastors:

- Are there any young people in your church who live without a father figure?

- If you said yes, are they less or more than the young people who live with their fathers?

- Does your church currently help young people with absent fathers?

- If you said yes, could you please tell me how your church helps them?

- Have you experienced any difficulty with helping these young people?

- If you have experienced difficulties, could you indicate any of the difficulties?

- Have you asked these young people what they need?

- If you have asked them, please tell me what they said.

- Do you read any books or articles to understand them?

- What do you think is the most important thing to consider when dealing with young people with absent fathers?

- Does your church have a programme to re-educate or retrain fathers and men to improve their family situation?

\section{Selection of participants}

\section{Father-absent adolescent participants}

Fifty-two father-absent adolescents of 18 years and over were recruited from 15 local churches from three of the nine South African provinces: Gauteng, Mpumalanga and Limpopo. In alphabetical order, every second one was chosen. Twenty-six participants were selected, but five of them were disqualified being under the age of 18 years. Thus, 21 father-absent adolescents participated in the interviews for this research.

\section{Ethical consideration}

Permission to conduct the study was granted by the Research Committee of the Faculty of Practical Theology of the University of Pretoria, as well as the individual participants in the study through informed consent.

Biological data of the father-absent adolescent participants are represented in Table 1.

\section{Local pastor participants}

Twenty-five senior pastors from 13 churches were recruited from three of the nine South African provinces: Gauteng, Mpumalanga and Limpopo. The number of interviews was limited to one per church. The researcher listed their names in alphabetical order in each of the 13 churches and randomly selected one from every church. Finally, 12 black local pastors, who were currently in charge of ministries, were invited to participate in qualitative research.

Information of the pastor participants are represented in Table 2. 
TABLE 1: The father-absent adolescent participants.

\begin{tabular}{|c|c|c|c|c|}
\hline $\begin{array}{l}\text { Code - Age - province } \\
\text { of participant }\end{array}$ & Gender & Employment & $\begin{array}{l}\text { Age of participant when } \\
\text { father became absent }\end{array}$ & Relationship with father \\
\hline FA01-24-MP & Female & Unemployed & Since her birth & None \\
\hline $\mathrm{FAO2}-27-\mathrm{MP}$ & Female & Part-time & 12 years & None \\
\hline FA03 - 18-MP & Female & Gr.12 & 6 years & Very poor \\
\hline $\mathrm{FA} 04-18-\mathrm{MP}$ & Male & Gr.12 & Since his birth & Very poor \\
\hline FA05-20-MP & Female & Gr.12 & Not sure & None \\
\hline FA06-28-MP & Female & Unemployed & 8 years & None \\
\hline FA07-20-MP & Male & Gr.10 & Not sure & Very poor \\
\hline FA08-21-MP & Female & Gap year & Not sure & None \\
\hline FA09-19-MP & Female & Gap year & Not sure & None \\
\hline FA10 - 27-MP & Female & Unemployed & 15 years & None \\
\hline FA11 - 24-LP & Female & Unemployed & 12 years & None \\
\hline $\mathrm{FA} 12-19-\mathrm{MP}$ & Female & Gr.12 & 6 years & Very poor \\
\hline $\mathrm{FA} 13-25-\mathrm{MP}$ & Female & Unemployed & Never knew him & None \\
\hline FA15-20-MP & Female & Gr.12 & Never knew him & None \\
\hline $\mathrm{FA} 16-18-\mathrm{MP}$ & Female & Gr.12 & Not sure & Very poor \\
\hline FA17-18-MP & Female & Gr.12 & Since her birth & Good \\
\hline FA18-28-LP & Male & Self-employed & 6 years & None \\
\hline FA19-21-GP & Female & Student of Unisa & 12 years & None \\
\hline $\mathrm{FA} 20-27-\mathrm{MP}$ & Male & Full-time & 13 years & None \\
\hline FA21 - 19-MP & Female & Gr.10 & 4 years & None \\
\hline
\end{tabular}

GP, Gauteng Province; LP, Limpopo Province; MP, Mpumalanga Province.

TABLE 2: The pastor participants.

\begin{tabular}{llll}
\hline $\begin{array}{l}\text { Code }- \text { Age }- \text { province of } \\
\text { participant }\end{array}$ & Gender & Marital status & $\begin{array}{l}\text { Type of employment as a } \\
\text { senior pastor }\end{array}$ \\
\hline P01-51-MP & Male & Married & Full-time \\
P02-52-MP & Female & Married & Full-time \\
P03-49-GP & Male & Married & Full-time \\
P04-49-MP & Female & Married & Part-time \\
P05-50-LP & Female & Married & Full-time \\
P06-44-MP & Female & Single & Part-time \\
P07-45-GP & Female & Married & Part-time \\
P08-43-MP & Female & Married & Part-time \\
P09-51-LP & Male & Married & Part-time \\
P10-50-GP & Male & Married & Full-time \\
P11-43-MP & Female & Married & Full-time \\
P12-44-MP & Female & Married & Part-time \\
\hline
\end{tabular}

GP, Gauteng Province; LP, Limpopo Province; MP, Mpumalanga Province.

In the same manner as with the adolescent participants' qualitative research, a letter of introduction and their informed consent to participate in academic research was discussed with them. The letter of introduction and their informed consent included confidentially or anonymity, the right to self-determination and that all information will be treated fairly and be kept anonymous by the researcher.

All participants signed the consent letter.

\section{Data gathering}

Interviews were conducted from August 2018 to October 2018. The researcher made an appointment with participants in the different communities to visit their churches and conduct the interviews. The participants were informed orally and in writing about the purpose of the research. The interviews were conducted at their churches according to their choice: either after Sunday service or during a week after their prayer meeting. All the venues were private, pleasant and comfortable. The interviews took approximately 30 minutes each. The data is based on direct storylines told by the participants without any influence from the researcher. This process gives credence to the outcome of the research.

\section{The outcome of the empirical research}

\section{The outcome of the interviews with father-absent adolescents}

\section{Description of participants' relationships with their fathers}

Eighteen of the 21 participants answered that they do not have contact with their biological fathers. Sixteen participants said that they were separated from their fathers from birth and at ages of 8 years (FA01, FA03, FA04, FA05, FA07, FA08, FA09, FA12, FA13, FA14, FA15, FA16, FA17, FA18, FA19 \& FA21). They did not have to share their lives and time with their fathers. Eleven participants indicated the 
last contact with their fathers was 10 to 20 years ago, from 1998 to 2008 (FA01, FA02, FA04, FA05, FA06, FA10, FA11, FA18, FA19, FA20 \& FA21). Ten participants said they do not know anything about their fathers (FA03, FA04, FA05, FA06, FA08, FA13, FA15, FA16, FA18 \& FA21). One interviewee who never knew her father said that since she was born, her father has not made any contact (FA15). Their mothers or grandmothers raised all participants while their biological fathers did not assist or support them. They wanted to have support from their fathers financially and emotionally.

\section{Description of the participants' awareness of father absence}

Ten participants state they have a negative feeling about the word father (FA01, FA03, FA04, FA05, FA06, FA07, FA08, FA09, FA12 \& FA19), using the words: bad, pain, nothing, problem, uncomfortable, sore, sad, difficult, meaningless and no exist. They expressed their deep bitter feelings about their absent fathers. One interviewee said with a disinterested attitude:

'He does not exist. I do not know anything about him. Even my family do not know him.' (FA15)

Eleven participants said that they have negative feelings about their absent father (FA02, FA10, FA11, FA13, FA14, FA15, FA16, FA17, FA18, FA20 \& FA21). They evaluated their fathers' behaviour as generally negative. Fifty-two per cent said that they do not have any negative feelings about their absent fathers, because they do not think about them anymore. Their absent fathers were unrelated to them.

However, 19 participants wished for a good relationship with their fathers (FA01, FA02, FA03, FA04, FA06, FA07, FA08, FA09, FA10, FA11, FA12, FA13, FA14, FA15, FA16, FA17, FA18, FA20 \& FA21). Even though they expressed anger (FA16) and felt betrayed and abandoned by their fathers (FA03), they longed for their father to be with them (FA01, FA09 \& FA14). Moreover, when they become parents, they wished to be emotionally close to their children, to support economically, and to provide protection.

\section{The influence of a father's absence on the participants' relationship with God}

All 21 participants expressed a positive feeling about God as Father and have a personal God-fearing faith. They indicated that they feel 'good' and 'okay' (FA03, FA04, FA05, FA06, FA09, FA10, FA11, FA13, FA14, FA15, FA16 \& FA21), 'happy' (FA01, FA08 \& FA19), 'comfortable' (FA07), 'strong' (FA20), 'nice' (FA18), 'amazing' and 'great' (FA02, FA12 \& FA17). Most of them unanimously expressed that, even though their biological father abandoned them and not present, God is there for them. God, the Heavenly Father never abandons them; and they are excited because they have a Father. They are convinced that God is the Father of their lives and are pleased to call God 'Father'. Particularly three participants have experienced negative feelings about God because of their absent fathers' abnormal and cruel behaviours such as abusing his pregnant wife, and have several marriages and divorces and thereby causing family to be scattered and wandering from relative to relative:

'My father abused my mother when she was pregnant. I asked myself what kind of father he was. I have complained to God, 'why me, why me ...' (FA04, 18 years old, Female)

'Each and every year he marries has kids and divorces. Where is his responsibility for kids?' (FA12, 19 years old, Female)

'There are a lot of question marks that I do not understand and a lot of confusion. It makes me have those negative thought even deeper about God.' (FA18, 28 years old, Male)

However, all participants have experienced the closeness and tenderness of God as the Father in their lives. When they feel down and sad when a family member is sick and when they pray, they felt the tenderness of God and unconditional love even though they feel that they do not deserve his love.

\section{Description of the context of the participants' relationship with pastors and church.}

Most participants would like their pastors or churches to help with financial support, spiritual support and support to build their characters. Eleven participants said that their pastor and church understand their painful feelings and difficult situation (FA01, FA06, FA07, FA09, FA11, FA12, FA13, FA14, FA18, FA19 \& FA20). They have a good relationship with their pastors, and they often speak to them. Especially when they have problems and need guidance, they freely ask their pastors.

But then, 10 participants said that their pastors and church do not understand their painful feelings and difficult situations (FA02, FA03, FA04, FA05, FA08, FA10, FA15, FA16, FA17 \& FA21), because they have not told their pastors (FA03, FA05, FA08, FA15, FA17 \& FA21). Due to a lack of relationship, they have not had an opportunity to talk to their pastors about their situations (FA02, FA04, FA10 \& FA16). So, if their pastors do not ask first, they do not talk to them about their painful feelings and difficult situations. Usually they do not speak with someone freely about their feelings and situations. They do not like people to feel pity for them, and they have experienced that a person who has heard about their feelings and situations, discouraged them. Eight participants indicated that they have not thought about their pastors or any church members as their fathers (FA03, FA04, FA05, FA09, FA10, FA12, FA13 \& FA18). One participant said that it was not easy for him to have a father figure, because he does not know what a 'father' is and what the 'father's role' should be (FA04).

The father-absent participants would like their church or pastor to support them to build their characters (17 times), to support them spiritually (14 times) and financially (9 times).

\section{The outcome of interviews with senior pastors of father-absent adolescents \\ Description of the participants' recognition of youth living without a father figure}

All participants answered that there are youth and small children living without a father in their church who are raised 
by teenager single mothers or grandparents. Ten of 12 participants currently help these young people, because most of them are from poor families (P01, P03, P04, P05, P06, P07, P08, P09, P10 \& P11). If these young people attend church on their own, it is difficult to figure out whether they are living without a father, because they tend not to report to the church or pastors until a good relationship with the pastors or the congregations has developed. The pastors help them to fill the void of a father figure with counselling (P01, P03, P04 \& P10) (P03, P06, P07, P08 \& P11) and give them some financial support (P04, P05 \& P09).

\section{The participants' descriptions of relationships with young people without a father figure}

The researcher found that seven participants said they have difficult experiences when they help young people who live without a father figure (P01, P04, P05, P07, P09, P10 \& P11) such as emotional difficulties (P05, P07, P09 \& P10), identification (P01), relationship (P11) and financial challenges (P04). They mentioned these children's sensitive emotion toward others due to anger, aggression and a feeling of rejection. Some of them appear uncomfortable with personal relationships and that causes a weak relationship between pastors and themselves.

Sometimes when pastors help them, they find that it infringes on their private life with regard to finances. If there is no church budget for these children, the pastor uses his or her own money and it pressurises on his or her private life.

Six participants said they have asked the young people what they need when they deal with them (P03, P05, P06, P07, P08 \& P09). Another six participants (P01, P02, P04, P10, P11, P12) have not asked what they need, but usually offer help when needed:

'I never ask them whether they need something whatever. I say that if he or she needs something or wants to talk to, I am here.' (P12, 44 years old, Female)

\section{Descriptions of the participants' awareness of father absence}

Ten participants indicated that they do not spend time learning about the absence of a father and to understand the situation of the children with absent or uninvolved fathers (P01, P02, P04, P05, P06, P07, P08, P09, P10 \& P12). Only two participants responded that they read articles or books to understand these children's situation, fatherhood, father figure and the relationship between fathers and children (P03 $\&$ P11). Eight participants said that they do not have any reeducation or a retraining programme for fathers and men in their churches (P03, P04, P05, P06, P07, P08, P09 \& P10). If the church is small and only has a few male church members, they are not concerned about the re-education or retraining of fathers and men. But if the church belongs to a denomination, they have the opportunity to join men's conferences regularly. Four participants said that they have an annual programme for fathers and men (P01, P02, P11 \& P12). Through a programme, they can learn about the father's role, how to build a good relationship between father and children, and how to help children without involved fathers to have a father figure.

\section{Summary of the findings Findings from adolescent participants who live without a father figure}

Twenty-one adolescent participants shared their situations and feelings of being brought up in families where the father is absent, and the figure of God as the Father. They also answered to their own experiences.

\section{Lack of father involvement}

All participants were raised by their mothers, grandparents or relatives who provided for their basic needs. Fifty-seven per cent of the participants did not know who their fathers are and where their fathers are. Most of them did not receive any form of support and assistance from their biological fathers or paternal relatives. The lack of father involvement caused a non-existing relationship between these adolescents and their father or paternal relatives. Usually, girls do not separate from their mothers until early adolescence. During that time, a father's social-emotional support can function as a 'bridge' between the mother and the larger society, allowing daughters to successfully negotiate the transition to autonomy and to be provided with opportunities for constructive interaction with males. Girls with absent or uninvolved fathers may remain relational disadvantaged when it comes to male pastors or church leaders (Snarey 1993:344).

\section{The aspiration toward father's love}

Even though these children felt unloved, abandoned and rejected by their biological fathers, they sought care, warmth, attention and have the desire to spend time with and share their lives with their fathers. When they become a father or mother they would like to be good parents. The church must be concerned enough to help them to reform their negative feelings about their fathers, and to form a biblical understanding of a 'father' and to appreciate the biblical value of family.

\section{The feeling toward God as Father}

The negative feelings about their absent fathers did not influence their feelings toward God as Father. All participants are convinced that the 'Heavenly Father' is there for them. They have an identity of being children of God.

\section{Lack of support from the church}

According to Lanker and Issler (2010), there is a very strong correlation between the presence of natural mentoring relationships and the spiritual development of adolescents. Natural mentoring relationships may touch aspects of adolescent life such as self-esteem, the overcoming of problem behaviour, preventing and reducing depression and reducing high-risk decisions (Haddad, Chen \& Greenberger 2011; Hurd \& Zimmerman 2010). Due to lack of support and father involvement, there is a need for a father figure and good role models 
within the congregation. The local church should be a place where young people are educated to be imprinted with religious and cultural values. The local church must provide various opportunities to guide young people without a father figure into adulthood and to take their place as members of society.

\section{Findings from senior pastor participants regarding adolescents without a father figure}

Twelve pastor participants who are currently in ministry opened their ministries and shared their experiences of these adolescents on how they understand them; how they relate with them; and how they help them in the church.

\section{In need of cultural support}

All pastor participants agreed that they must be concerned about these young people's sensitive feelings and emotions, because adolescence is a specific and unique period of life. It seems, however, that local pastor participants do not motivate the need for training to understand youth culture. Pastors as leaders of churches are expected to have an understanding and professional knowledge on all matters relating youth culture and youth developmental processes.

\section{Responsibilities of the local church}

Root (2007b:129-130) discusses a 'relational youth ministry', and states:

We often neglect to understand that their suffering is an invitation to enter gently into relationships of place-sharing. ... Rarely discussed is our vicarious responsibility for the full humanity of the adolescent. ... We may have taught them that God cares and that their sufferings can be brought to the foot of the cross, but have we placed ourselves at the foot of this same cross, saying, 'Let me carry your pain with you, and in our mutual suffering God will minister to us'?

The church must not fail to notice the needs of adolescents with absent fathers and must take responsibility as the one body of Christ. These adolescents require good examples of fathers and mentors that they can follow and adhere to. Programmes are needed to reduce the negative effect of the absence of a father on adolescent behaviour. The local church has the responsibility as an extended family, to care for these young people and to develop a counterplan.

\section{The quality of the local pastor and congregation}

Pastors are required to have professional knowledge and information, in order to have a sound perspective and understanding of youth ministry. They must have knowledge about youth culture and have a sound theology to deal with youth in the local church. The local church must provide re-education programmes for the congregation, to improve their families and to embrace young people with absent or uninvolved fathers as their family members. The congregation must be a role model for their children and young people.

\section{Suggestions for remedial action}

The article presents several suggestions on 'what we as church leaders can do differently and better', based on the data from the empirical research:

- A stable relationship between youth with absent fathers and pastors is needed. Root (2007a:141) states that relationships are the concrete place where we meet the transcendent otherness of God in God's revelation and subsequently become place-sharers for young people'.

- A personal study of the influence of fathers and absent fathers on children and adolescent development is needed. There should be continued and systematic education for pastors and youth pastors in order to have sound perspectives and understanding about these young people. They need to learn the concepts of youth ministry, various children and adolescents developmental theories, psychotherapy, et cetera, which is useful to deal with the congregation in local churches.

- $\quad$ Nel (2018:154) says:
... youth being an integral part of the faith community with its many adults is that it is in this passionate community that we help and support each other to become who God planned us to be in this world.

To help and support young people who are in the local church and those yet to come, a personal study of the adolescents' culture is needed.

- Budgeting by the congregation for adolescents who live without a father figure, is a dire need. These adolescents were not receiving enough care and support from their church. During the interviews, the adolescents dropped hints about their expectations regarding constant care and support.

- Expand the family to the church community in order to embrace adolescents who live without a father figure. The faith community must offer their youth a rich spiritual heritage. The Christian faith community has stories about 'our Heavenly Father' to pass on to the younger generations. The values and priorities of the children of God arise from deep and intimate relationships with 'God, our Heavenly Father'.

- Help adolescents with absent or uninvolved fathers to discover their identity: 'who they are', and 'the purpose of the life'. Through the discovery of their identity, they will sever the vicious circle of father's absence, and they can be good parents.

\section{Conclusion}

The aim of the article was to address the lack of theological perspective and an inclusive and congregational approach to the adolescents who live without a father figure leading to an ineffective and inefficient youth ministry in the local church. Through empirical research, the article described how these young people feel about the absence of their 
fathers and God as the Father in their life. The article also indicated the situation of the local church with young people with absent fathers and identified that there is a lack of interaction between them and pastors and/or congregations. There is a need for further empirical research in this field, as these young people are an integral but still neglected part of youth ministry. Nel (2018:215-217) suggests three consequences of the theological justification. The first is that, although unique, it is never separated from the rest of the faith community. Young people need to be able to serve in different ways than adults. The second consequence is that the youth should never be ignored. Young people are an integral part of God's people and the body of Christ. The third consequence is that youth are the responsibility of the whole faith community. They must have a place to participate in God's action. These are the positions and the place where young people with uninvolved fathers must take within the congregation to fulfil their purpose in the local church.

\section{Acknowledgement Competing interest}

The authors have declared that no competing interests exist.

\section{Authors' contributions}

This is a contribution of H.Y. toward a $\mathrm{PhD}$ in Practical Theology with the University of Pretoria, in the field of youth ministry. M.N. served as a supervisor.

\section{Funding information}

This research received no specific grant from any funding agency in the public, commercial or not-for-profit sectors.

\section{Data availability statement}

Data sharing is not applicable to this article as no new data were created or analysed in this study.

\section{Disclaimer}

The views and opinions expressed in this article are those of the authors and do not necessarily reflect the official policy or position of any affiliated agency of the authors.

\section{References}

Breed, G. \& Semenya, K., 2015, 'Ubuntu, koinonia and diakonia, a way to reconciliation in South Africa?', HTS Teologiese Studies/Theological Studies 71(2), Art. \#2979, 9 pages. https://doi.org/10.4102/hts.v71i2.2979

Bronte-Tinkew J., Carrano, J., Horowitz, A. \& Kinukawa, A., 2008, 'Involvement among resident fathers and links to infant cognitive outcomes', Journal of Family Issues 29(9), 1211-1244. https://doi.org/10.1177/0192513X08318145

Bush, K.R. \& Peterson, G.W., 2013, 'Parent-child relationships in diverse contexts', in G.W. Peterson \& K.R. Bush (eds.), Handbook of marriage and the family, 3rd edn., pp. 275-302, Springer, New York.

Callahan, K.L., 1994, Dynamic worship: Mission, grace, praise, and power: A manua for strengthening the worship life of twelve keys congregations, Harper Collins Publishers, New York.

Callahan, K.L., 2010, Twelve keys to an effective church, 2nd edn., Jossey-Bass, San Francisco, CA.
Dean, K.C., 2010, Almost Christian: What the faith of our teenagers is telling the American church, Oxford University Press, New York.

Dean, K.C. \& Foster, R., 1998, The Godbearing life - The art of soul tending for youth ministry, Upper Room Books, Nashville, TN.

DeVries, M., 1994, Family-based youth ministry, InterVarsity Press, Westmont, IL.

Dietrich, S., Jorgensen, K., Korslien, K.K. \& Nordstokke, K. (eds.), 2014, Diakonia as Christian social practice, Regnum Books International, Oxford.

Eisenberg, N. \& Morris, A.S., 2004, 'Moral cognition and prosocial responding in adolescence', in R.M. Lerner \& L. Steinberg (eds.), Handbook of adolescent psychology, pp. 155-188, 2nd edn., John Wiley \& Sons, Inc., Edison, NJ.

Erikson, E.H., 1963, Childhood and society, 2nd edn., Norton, New York.

Forrester, D., 2005, Theological fragment: Explorations in unsystematic theology, T\&T Clark, New York.

Haddad, E., Chen, C. \& Greenberger, E., 2011, 'The role of important non-parental adults (VIPs) in the lives of older adolescents: A comparison of three ethnic groups', Journal of Youth and Adolescence 40(3), 310-319. https://doi. org/10.1007/s10964-010-9543-4

Hall, K. \& Sambu, W., 2016, Demography of South Africa's children, University of Cape Town, viewed 28 Jan. 2018, from www.ci.uct.ac.za/sites/default/files/image-tool/ images/367/Child_Gauge_2016-children_count_demography_of_sa_children.pdf

Heitink, G., 1999, Practical theology: History, theory, action domains: Manual for practical theology, Eerdmans, Grand Rapids, MI.

Hoffman, M.L., 1996, 'Empathy and moral development: Implications for caring and justice', The Annual Report of Educational Psychology in Japan 35, 157-162. https://doi.org/10.5926/arepj1962.35.0_157

Hurd, N. \& Zimmerman, M., 2010, 'Natural mentors, mental health, and risk behaviours: A longitudinal analysis of African-American adolescents transitioning into adulthood', American Journal of Community Psychology 46(1-2), 36-48. https://doi.org/10.1007/s10464-010-9325-x

Jacober, A., 2011, The adolescent journey: An interdisciplinary approach to practical youth ministry, InterVarsity Press, Downer Grove, IL.

Krohn, F.B. \& Bogan, Z., 2001, 'The effects absent fathers have on female development and college attendance', College Student Journal 35(4), 598-609.

Lanker, J. \& Issler, K., 2010, 'The family of faith: The place of natural mentoring in the church's Christian formation of adolescents', Christian Education Journal 7(2), 267-280. https://doi.org/10.1177/073989131000700202

Lewis, C., 1997, 'Fathers and pre-schoolers', in M.E. Lambs (ed.), The role of the father in child development, pp. 121-142, John Wiley, New York.

Makusha, T., Richter, L. \& Chikovore, J., 2013, 'Fatherhood and masculinities in South Africa', in D. Gennrich (ed.), Men and masculinities in South Africa, vol. 2, Understanding masculinity in South Africa-Essays and perspectives, pp. 71-78, PACSA \& Sonke Gender Justice Network, Pietermaritzburg, viewed 18 May 2018, from www.pacsa.org.za/images/docs/men-and-masculinities-in-south-africavolume-2.pdf

Meyer, J., 2018, 'Restructuring the Christian fatherhood model: A practical theological investigation into the male problematic of father absence', HTS Teologiese Studies/Theological Studies 74(1), 4870. https://doi.org/10.4102/hts.v74i1.4870

Mosotho, L., Louw, D.A. \& Calitz, F., 2011, 'The manifestation of anxiety among Sesotho speakers', South African Journal of Psychology 41(4), 437-450. https:// doi.org/10.1177/008124631104100404

Nel, M., 2000, Youth ministry - An inclusive congregational approach, Design Books, Pretoria.

Nel, M., 2001, 'The inclusive congregational approach to youth ministry', in M.H. Senter (ed.), Four views of youth ministry and the church, pp. 1-38, Zondervan Publishing House, Grand Rapids, MI.

Nel, M., 2005, Who are we? Understanding and finding identity in the local church, Kitskopie, Pretoria.

Nel, M., 2009, 'Congregational analysis: A theological and ministerial approach', HTS Teologiese Studies/Theological Studies 65(1), Art. \#303, 17 pages. https://doi. org/10.4102/hts.v65i1.303

Nel, M., 2018, Youth Ministry: An inclusive missional approach, HTS Religion \& Society, 1, p. i-420, AOSIS (Pty), Cape Town.

Oswald, H. \& Süss, K., 1994, 'The influence of parents and peers on misconduct at school: Simultaneous and synergistic effects', in R.K. Silbereisen \& E. Todt (eds.) Adolescence in context: The interplay of family, school, peers, and work in adjustment, pp. 347-365, Springer-Verlag, New York.

Piaget, J., 1972, 'Intellectual evolution from adolescence to adulthood', Human Development 15(1), 1-12. https://doi.org/10.1159/000271225

Rohner, R.P., 2004, 'The parental acceptance-rejection syndrome: Universal correlates of perceived rejection', The American Psychologist 59(8), 827-840. https://doi. org/10.1037/0003-066X.59.8.830

Root, A., 2007a, Revisiting relational youth ministry: From a strategy of influence to a theology of incarnation, InterVarsity Press, Downers Grove, IL.

Root, A., 2007b, 'Youth ministry as an integrative theological task: Toward a representative method of interdisciplinarity in scholarship, pastoral practice, and pedagogy', Journal of Youth Ministry 5(2), 33-50.

Root, A., 2013, The relational pastor: Sharing in Christ by sharing ourselves, InterVarsity Press, Downers Grove, IL.

Santrock, J., 2007, Adolescence, 11th edn., McGraw Hill, New York.

Schnase, R., 2007, Five practices of fruitful congregations, Abingdon Press, Nashville, TN. 
Schulze, A.C., 2012, 'Key factors of faith development: The relationship between family and church factors and faith development of adolescents and young adults in German-speaking Europe, Dissertations, 688, Andrew University, School of Education, viewed 05 May 2017, from https://digitalcommons.andrews.edu/
dissertations/688.

Smith, C. \& Denton, M.L., 2005, Soul searching: The religious and spiritual lives of American teenagers, Oxford University Press, Inc., Oxford.

Snarey, J.R., 1993, How fathers care for the next generation: A four-decade study, Harvard University Press, Cambridge, MA.

Spence, J.T. \& Hall, S.K., 1996, 'Children's gender-related self-perceptions, activity preferences, and occupational stereotypes: A test of three models of gender constructs', Sex Roles 35(11), 659-691. https://doi.org/10.1007/BF01544086

Statistics South Africa (Stats SA), 2015, Marriages and divorces, Government Printing Works, Pretoria.

Statistics South Africa (Stats SA), 2017, Mid-year population estimates 2016 Government Printing Works, Pretoria.
Statistics South Africa (Stats SA), 2018, Unemployment rate, Government Printing Works, Pretoria.

Stinson, R. \& Jones, T.P. (eds.), 2011, Trained in the fear of God: Family ministry on theological, historical and practical perspectives, Kregel Publications, Grand Rapids, MI.

Thomas, S., 2017, 'Why divorce is on the rise in SA: And fewer South African are getting married', Financial Mail, 14 September, viewed 22 May 2018, from www.businesslive.co.za/fm/fm-fox/2017-09-14why-divorce-is-on-the-rise-in-sa.

UNICEF South Africa, 2011, Child protection-orphans and vulnerable children, viewed 20 May 2018, from https://www.unicef.org/protection/6631.

Walker, L.J. \& Hennig, K.H., 1999, 'Parenting style and the development of moral reasoning', Journal of Moral Education 28(3), 359-374. https://doi.org/10.1080/ 030572499103133

Wilson, F., 2006, 'On being a father and poor in southern Africa today', in L. Richter \& R. Morrell (eds.), Baba: Men and fatherhood in South Africa, pp. 26-37, Human Sciences Research Council Press, Cape Town. 